\title{
PECVD-ONO: A New Deposited Firing Stable Rear Surface Passivation Layer System for Crystalline Silicon Solar Cells
}

\author{
M. Hofmann, ${ }^{1}$ S. Kambor, ${ }^{1}$ C. Schmidt, ${ }^{1}$ D. Grambole, ${ }^{2}{ }^{\text {J. }}$ Rentsch, ${ }^{1}$ \\ S. W. Glunz, ${ }^{1}$ and R. Preu ${ }^{1}$ \\ ${ }^{1}$ Fraunhofer Institute for Solar Energy Systems, Heidenhofstrasse 2, 79110 Freiburg, Germany \\ ${ }^{2}$ Forschungszentrum Dresden-Rossendorf, Bautzner Landstrasse 128, 01328 Dresden, Germany
}

Correspondence should be addressed to M. Hofmann, marc.hofmann@ise.fraunhofer.de

Received 17 January 2008; Accepted 6 March 2008

Recommended by Armin Aberle

A novel plasma-enhanced chemical vapour deposited (PECVD) stack layer system consisting of a-SiO $: \mathrm{H}, \mathrm{a}-\mathrm{SiN} x: \mathrm{H}$, and a-SiO$x: \mathrm{H}$ is presented for silicon solar cell rear side passivation. Surface recombination velocities below $60 \mathrm{~cm} / \mathrm{s}$ (after firing) and below $30 \mathrm{~cm} / \mathrm{s}$ (after forming gas anneal) were achieved. Solar cell precursors without front and rear metallisation showed implied open-circuit voltages $V_{\text {oc }}$ values extracted from quasi-steady-state photoconductance (QSSPC) measurements above $680 \mathrm{mV}$. Fully finished solar cells with up to $20.0 \%$ energy conversion efficiency are presented. A fit of the cell's internal quantum efficiency using software tool PC1D and a comparison to a full-area aluminium-back surface field (Al-BSF) and thermal SiO ${ }_{2}$ is shown. PECVDONO was found to be clearly superior to Al-BSF. A separation of recombination at the metallised and the passivated area at the solar cell's rear is presented using the equations of Fischer and Kray. Nuclear reaction analysis (NRA) has been used to evaluate the hydrogen depth profile of the passivation layer system at different stages.

Copyright (C) 2008 M. Hofmann et al. This is an open access article distributed under the Creative Commons Attribution License, which permits unrestricted use, distribution, and reproduction in any medium, provided the original work is properly cited.

\section{Introduction}

Electrical rear surface passivation is becoming increasingly important in crystalline silicon solar cell technology. The main reason for that is the need for a cost decrease in the photovoltaic sector. This leads to wafers that are becoming thinner and thinner and a steadily increasing need for higher energy conversion efficiencies. The result of both trends is an increased importance of an effectively passivated rear surface. In Figures 1 to 3 , simulations on rear surface passivation and cell thickness are presented using PC1D [1]. Open-circuit voltage $V_{\text {oc }}$ and energy conversion efficiency $\eta$ depend strongly on the rear surface recombination velocity (SRV) $S_{\text {eff }}$ when high-quality silicon substrates are taken into account $\left(\tau_{\text {bulk }}=750 \mu \mathrm{s}\right.$, excellent optics, front emitter, and passivation, Figure 1). For $S_{\text {eff }}$ values in the range of $5 * 10^{1} \mathrm{~cm} / \mathrm{s}$ to $5 * 10^{3} \mathrm{~cm} / \mathrm{s}$, the strongest interdependence was found. The thinner the solar cells the stronger this effect appears. Note that very thin solar cells $(50 \mu \mathrm{m})$ show a higher $V_{\text {oc }}$ level at very low $S_{\text {eff }}$ values while the $50 \mu \mathrm{m}$ cells suffer from a decreased light trapping in our simulation and convert the light a little less efficiently to electricity at the maximum power point. When looking at medium-efficient solar cells $\left(\tau_{\text {bulk }}=100 \mu\right.$ s, excellent optics, front emitter, and passivation, Figure 2) the influence of the rear passivation increases when the cells are getting thinner. We found that the thinnest cells show even better efficiencies than thicker cells when an excellent rear passivation is applied. Lowefficiency cells $\left(\tau_{\text {bulk }}=10 \mu \mathrm{s}\right.$, excellent optics, standard front emitter $50 \Omega /$ sq, and low-level front passivation, Figure 3 ) show only a slight dependence on the rear passivation due to a low diffusion length $\left(\tau_{\text {bulk }}=10 \mu \mathrm{s} \rightarrow\right.$ approximately $\left.L_{\text {eff }}=170 \mu \mathrm{m}\right)$. Hence, most minority carriers do not profit from a low rear recombination velocity but recombine in the bulk silicon. The thinner the low-efficient cells become, the more pronounced will be the influence of a good rear passivation.

Agostinelli et al. [2] have shown that silicon solar cells on very thin substrates (down to $105 \mu \mathrm{m}$ ) can reach higher efficiencies compared to a standard Al-BSF rear structure when an adapted rear surface passivation is applied. Kray [3] has presented energy conversion efficiencies above $20 \%$ for 


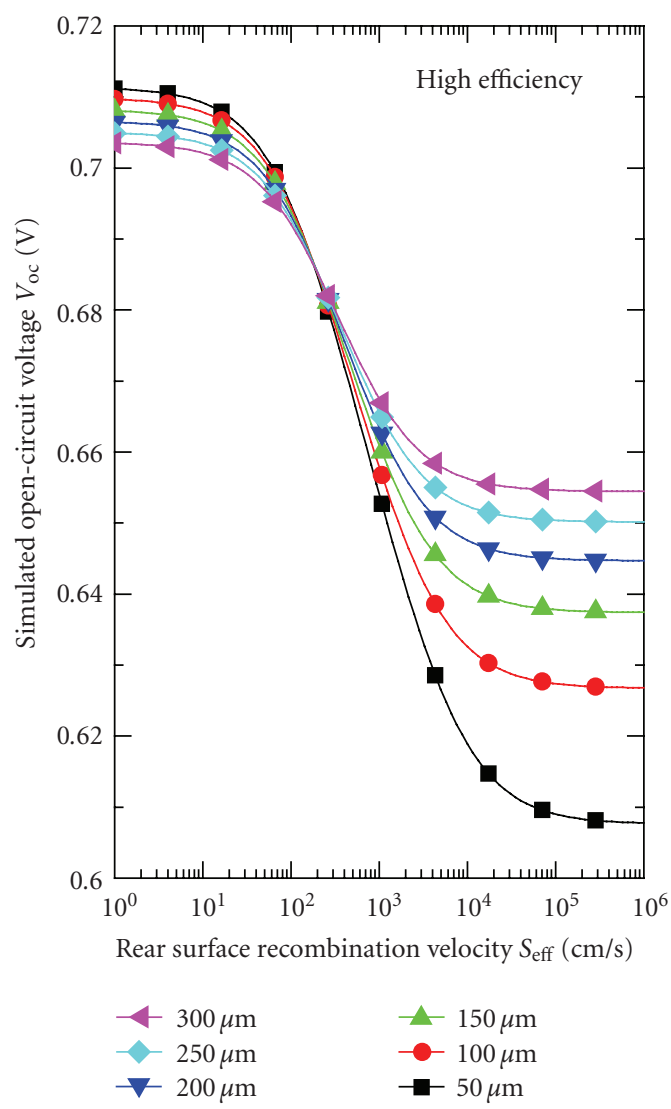

(a)

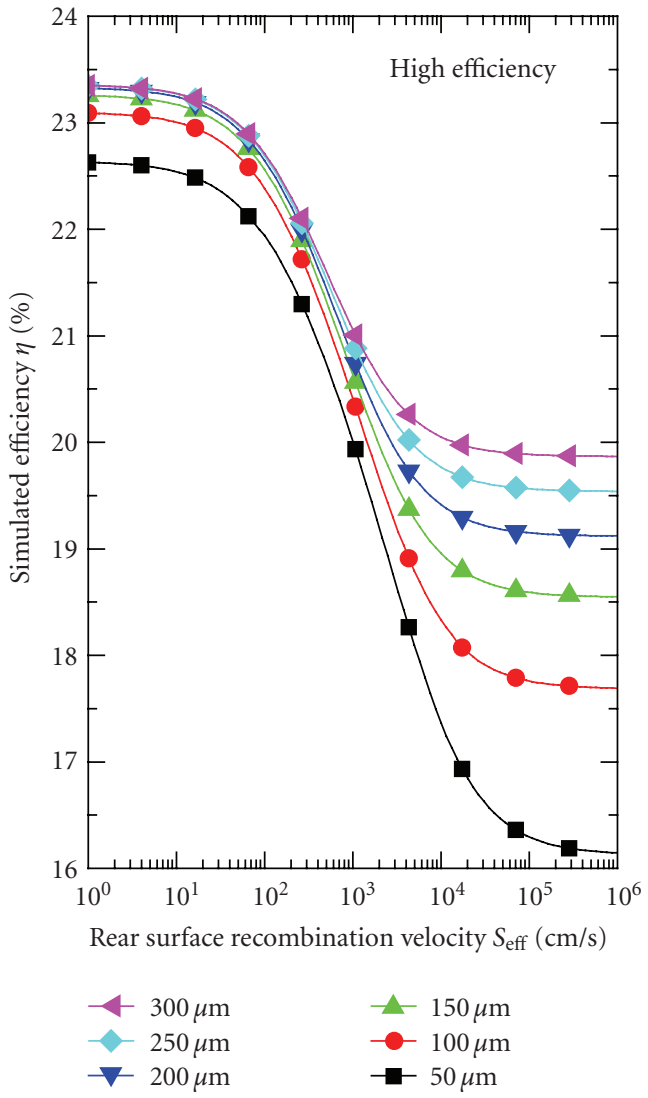

(b)

FIGURE 1: Simulated open-circuit voltage $V_{\mathrm{oc}}$ (left) and simulated energy conversion efficiency $\eta$ versus the effective rear surface recombination velocity $S_{\text {eff }}$ for high-efficiency solar cells. Calculated using PC1D. Parameters: $N_{A}=3 * 10^{16} \mathrm{~cm}^{-3}, \tau_{\text {bulk }}=750 \mu \mathrm{s}($ approx. Auger limit), textured front, front emitter: $120 \Omega / \mathrm{sq}, S_{\text {front }}=1000 \mathrm{~cm} / \mathrm{s}$.

substrates with less than $50 \mu \mathrm{m}$ thickness. Both publications make use of the passivated emitter and rear cell (PERC) concept [4].

Fraunhofer ISE has developed an economically feasible technology for mass production of the local rear contacts of PERCs [4] by implementing a laser technology. This patented laser-fired contacts (LFCs) approach [5] allows the local aluminium contact firing through a passivating - and in most cases isolating - layer system in approximately 1 to 3 seconds per cell. Within the same step, aluminium is alloyed into the silicon forming a $\mathrm{p}^{+}$regime underneath the local contact creating a very good ohmic contact at the cell's rear $[6,7]$.

Rear side surface passivation schemes need to be adapted to the LFC process and to the industrial production environment. The most common layers are thermally grown silicon dioxide $\left(\mathrm{SiO}_{2}\right)$, plasma-enhanced chemical vapour deposited (PECVD) hydrogenated amorphous silicon nitride $\left(\mathrm{a}-\mathrm{SiN}_{x}: \mathrm{H}\right.$, in short: $\left.\mathrm{SiN}\right)$, and PECVD hydrogenated amorphous silicon (a-Si:H, in short: a-Si). As thermally grown silicon dioxide $\left(\mathrm{SiO}_{2}\right)$ layers are manufactured by a timeand energy-intensive high temperature process, they are not the first choice for mass production, although they possibly provide a very good and thermally stable passivation [8].
Unfortunately, the temperature level is not suitable for every material quality. Especially, low-cost wafers might degrade during an oxidation process.

$\mathrm{SiN}$ films are fabricated by a low temperature processing step (approximately $300-400^{\circ} \mathrm{C}$ ). They also provide a very good passivation quality [9-15] but are not as thermally stable as $\mathrm{SiO}_{2}$ layers [8]. The thermal stability of optimised $\mathrm{SiN}$ layers can be improved to a degree that is sufficient for the typical thermal budget of the solar cell production line excluding emitter diffusion. Additionally, the cells passivated with SiN films typically suffer from an inversion layer which is shunted by the local rear contacts $[16,17]$. The inversion layer is due to a high density of fixed positive charges which typically can be found in SiN films.

Good a-Si films provide a very efficient surface passivation without forming such an inversion layer as a-Si films do not mainly passivate via a field effect but through the lowering of the density of states at the interface $D_{\text {it }}$. Different groups have been using a-Si as passivation, either as single layer a-Si passivation [18], a-Si stacks $[19,20]$ or a-Si stacked with SiN [21, 22], or PECVD silicon oxide $\left(\mathrm{SiO}_{x}\right)$ [23]. Not only intrinsic but also doped a-Si layers have been used. The major drawback when using a-Si passivation layers in crystalline silicon solar cell technology is the relatively low 


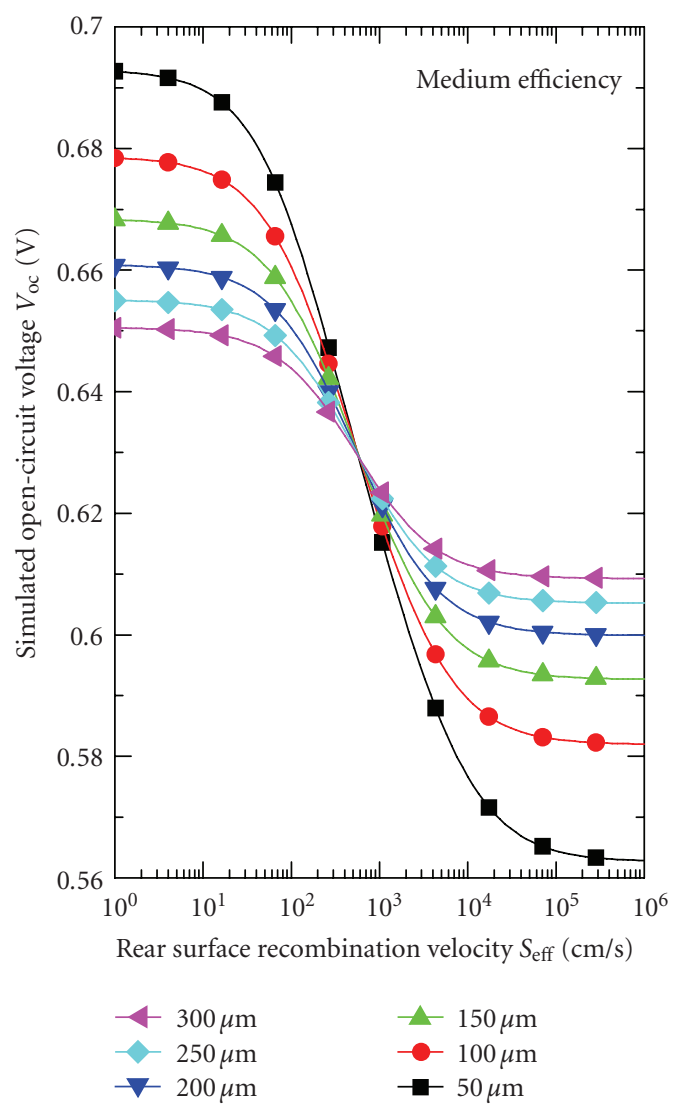

(a)

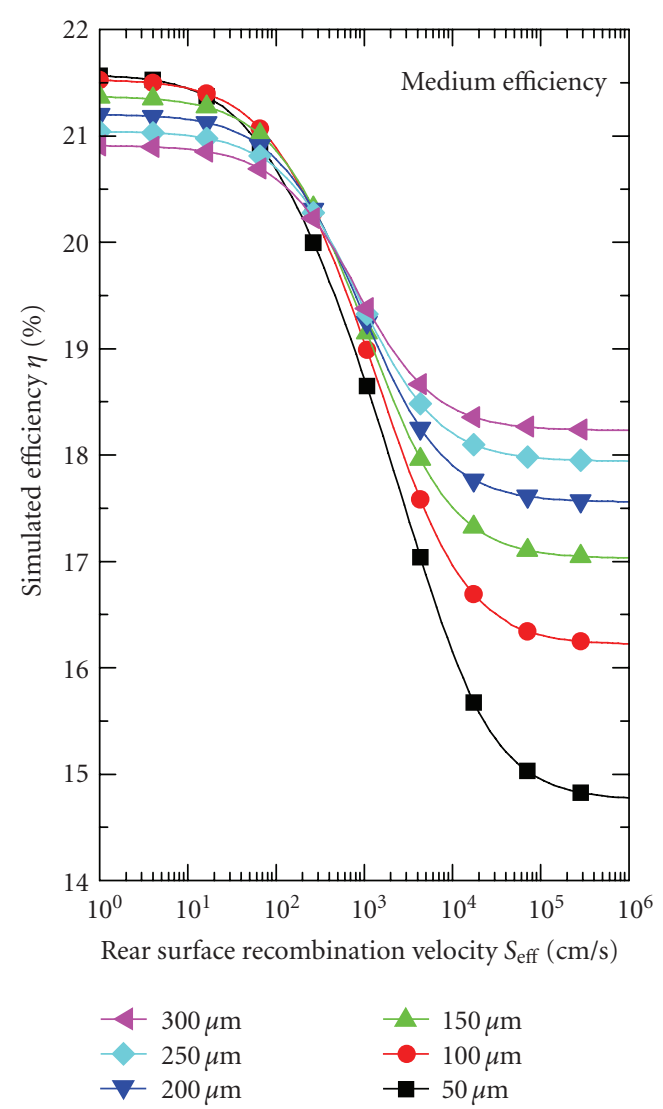

(b)

FIGURE 2: Simulated open-circuit voltage $V_{\mathrm{oc}}$ (left) and simulated energy conversion efficiency $\eta$ versus the effective rear surface recombination velocity $S_{\text {eff }}$ for medium-efficiency solar cells. Calculated using PC1D. Parameters: $N_{A}=7 * 10^{15} \mathrm{~cm}^{-3}, \tau_{\text {bulk }}=100 \mu \mathrm{s}$, textured front, front emitter: $120 \Omega / \mathrm{sq}, S_{\text {front }}=1000 \mathrm{~cm} / \mathrm{s}$.

thermal stability of the passivation properties. After a typical screen printed contact firing step with temperatures of up to $\sim 850^{\circ} \mathrm{C}$ the passivation properties are strongly reduced [24].

Therefore, an alternative passivation layer system that

(i) can be deposited quickly and easily at low temperatures, preferably using PECVD,

(ii) provides good passivation without a significant shunting,

(iii) is thermally stable in a contact firing process at $\sim 850^{\circ} \mathrm{C}$,

(iv) provides a compatible internal rear surface reflectance

would be a very good way to incorporate an effective surface passivation layer system in today's industrial solar cells.

\section{Lifetime Investigation}

\subsection{Symmetric Sample Structure}

As described above, thermally grown silicon dioxide layers provide all major requirements to be suitable for the rear passivation for silicon solar cells: good surface passivation, good rear reflectance, and thermal stability in solar cell production processes. Only the process throughput and cost and the possible degradation of the solar cell precursors seem to be the major and crucial problem.

PECVD silicon oxide layers $\left(\mathrm{SiO}_{x}\right)$ look like a possible alternative to combine the good layer characteristics of an $\mathrm{SiO}_{2}$ film with the benefits of PECVD. Regrettably, no PECVD $\mathrm{SiO}_{x}$ layers could be found by the authors that show a good surface passivation and thermal stability, no matter if the layer has been annealed in different gas ambient (e.g., forming gas) or not. Hence, different stack layers have been under investigation with the PECVD $\mathrm{SiO}_{x}$ layer being the first layer deposited (sitting directly on the wafer's surface).

It should be noted that an investigation of deposited oxide layers stacked with PECVD $\mathrm{SiN}_{x}$ has been presented by Agostinelli et al. [25].

Hoex et al. have presented well-passivating $\mathrm{SiO}_{x}$ films deposited by the expanding thermal plasma (ETP) technique [26].

The lifetime investigation has been performed using silicon wafers as substrates with the following properties: float zone, p-type, boron doped, $1 \Omega \mathrm{cm}, 250 \mu \mathrm{m}$ thick, and shiny etched surfaces with a crystal orientation of (100) [27]. The wafers were cleaned with a wet chemical RCA clean 


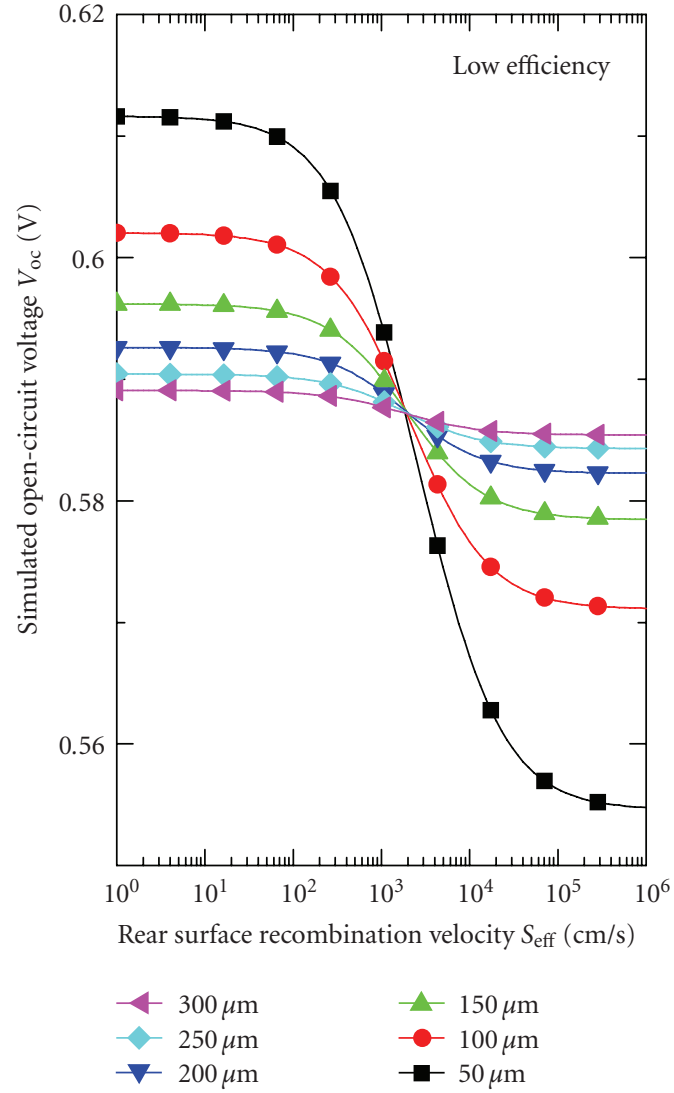

(a)

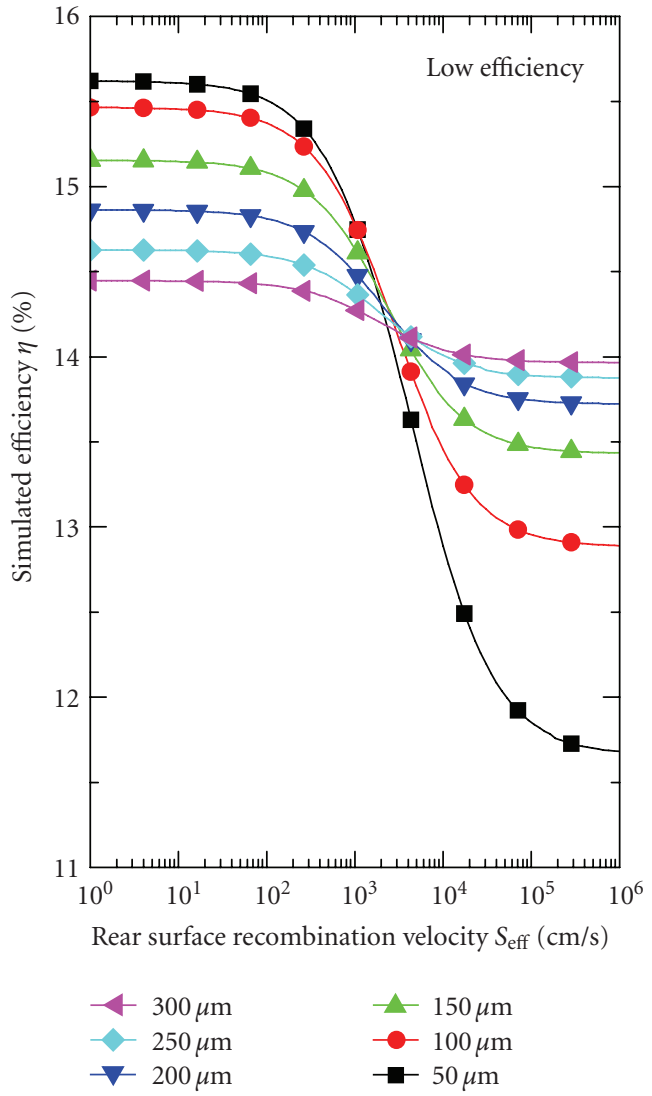

(b)

FIGURE 3: Simulated open-circuit voltage $V_{\mathrm{oc}}$ (left) and simulated energy conversion efficiency $\eta$ versus the effective rear surface recombination velocity $S_{\text {eff }}$ for low-efficiency solar cells. Calculated using PC1D. Parameters: $N_{A}=7 * 10^{15} \mathrm{~cm}^{-3}, \tau_{\text {bulk }}=10 \mu \mathrm{s}$, textured front, front emitter: $50 \Omega / \mathrm{sq}, S_{\text {front }}=10^{6} \mathrm{~cm} / \mathrm{s}$.

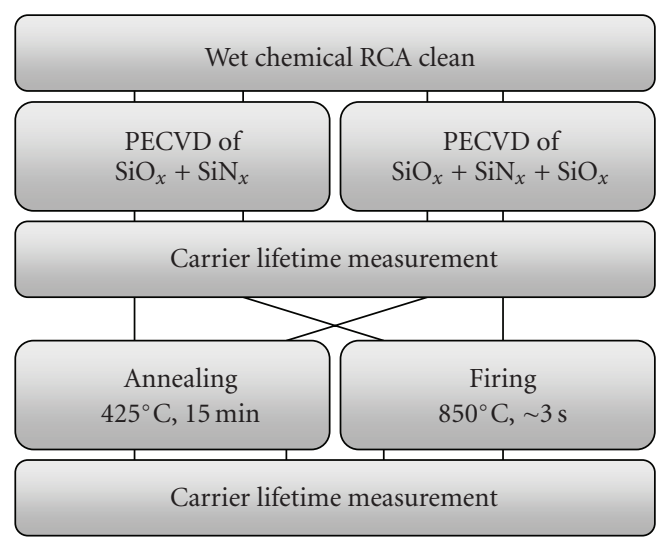

FIGURE 4: Work flow of the lifetime experiment on symmetric sample structures.

bath sequence [28] including a final dip in hydrofluoric acid (HF) and subsequently, the deposition on both surfaces of the wafers has been performed. Two different PECVD stack layer systems have been investigated: (i) $\mathrm{SiO}_{x}$ and $\mathrm{SiN}_{x}$ and (ii) $\mathrm{SiO}_{x}, \mathrm{SiN}_{x}$, and $\mathrm{SiO}_{x} \cdot \mathrm{SiO}_{x}$ always has been the first layer deposited. The deposition took place in a parallel plate PECVD reactor using a plasma excitation frequency of $13.56 \mathrm{MHz}$ and a gas mixture of monosilane $\left(\mathrm{SiH}_{4}\right)$ and nitrous oxide $\left(\mathrm{N}_{2} \mathrm{O}\right)$ for the $\mathrm{SiO}_{x}$ layer and monosilane, hydrogen $\left(\mathrm{H}_{2}\right)$ and nitrogen $\left(\mathrm{N}_{2}\right)$ for the $\mathrm{SiN}_{x}$ layer. The deposition temperature for all layers was $350^{\circ} \mathrm{C}$. The oxide layers can be deposited very quickly at a deposition rate of $\sim 120 \mathrm{~nm} / \mathrm{min}$. The nitride layer takes longer, at a rate of $\sim 8 \mathrm{~nm} / \mathrm{min}$. Thicknesses of $120 \mathrm{~nm}$ for the oxide and $70 \mathrm{~nm}$ for the nitride layers have been applied. See Figure 4 for the process sequence and Figure 5 for the sample structures.

Minority carrier lifetimes were measured using the quasisteady-state photoconductance (QSSPC) method [29]. The surface recombination velocity has been calculated from the measured lifetimes assuming that only Auger recombination took place in the sample's bulk (i.e., "perfect bulk"). The Auger model by Glunz et al. [30] has been applied for the calculation using the following equation [31]:

$$
\frac{1}{\tau_{\text {eff }}}=\frac{1}{\tau_{b}}+\left(\frac{W}{2 S_{\text {eff }}}+\frac{1}{D_{n}}\left(\frac{W}{\pi}\right)^{2}\right)^{-1},
$$

with the silicon wafer's bulk lifetime $\tau_{b}$, the wafer thickness $W$, the effective surface recombination velocity (SRV) $S_{\text {eff }}$, and the diffusion constant for electrons $D_{n}$. 

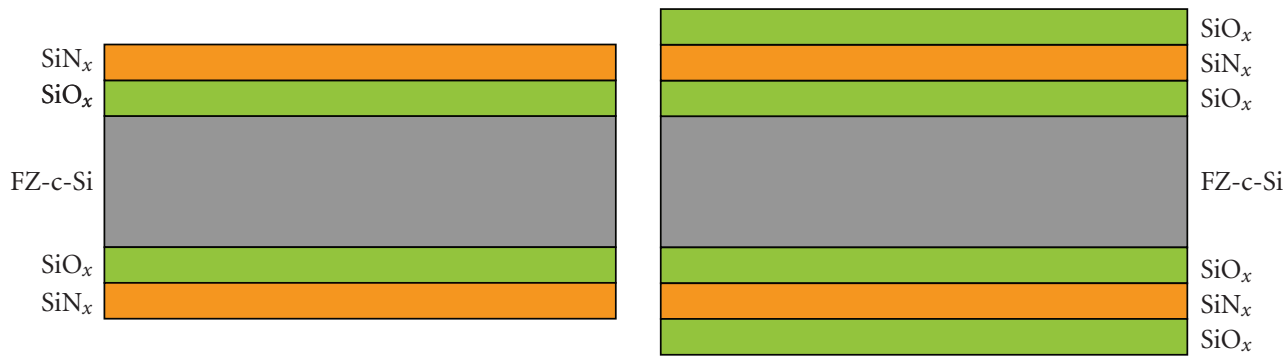

FIGURE 5: Symmetrical lifetime sample structures. Left: double layer sample structure $\mathrm{SiO}_{x}+\mathrm{SiN}_{x}$. Right: triple layer sample structure SiO , $\mathrm{SiN}_{x}$ and $\mathrm{SiO}_{x}(\mathrm{PECVD}-\mathrm{ONO})$.

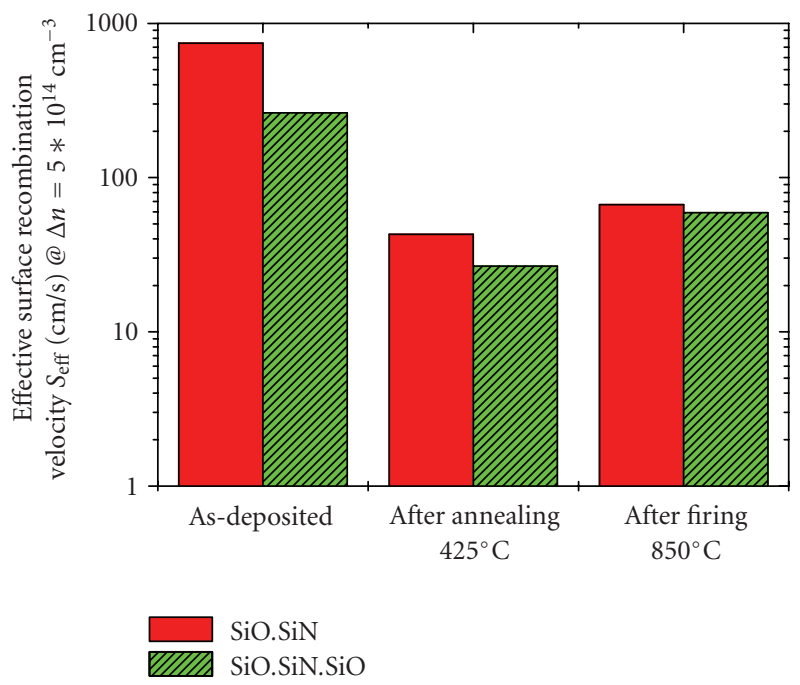

FIGURE 6: Effective surface recombination velocities of PECVD stacks of $\mathrm{SiO}_{x}+\mathrm{SiN}_{x}$ (left red columns) and $\mathrm{SiO}_{x}, \mathrm{SiN}_{x}$ and $\mathrm{SiO}_{x}$ (right green striped columns, PECVD-ONO) as-deposited, after annealing $\left(425^{\circ} \mathrm{C}, 15 \mathrm{~min}\right.$, forming gas $)$ or firing $\left(850^{\circ} \mathrm{C}, \sim 3 \mathrm{~s}\right)$.

The stack system of PECVD $\mathrm{SiO}_{x}$ and $\mathrm{SiN}_{x}$ led to as-deposited $S_{\text {eff }}$ values below $700 \mathrm{~cm} / \mathrm{s}$. Subsequently, an annealing in forming gas at $425^{\circ} \mathrm{C}$ for 15 minutes has been performed. Minority carrier lifetime measurements at this stage showed $S_{\text {eff }}$ values below $50 \mathrm{~cm} / \mathrm{s}$. Next, a thermal treatment comparable to firing of screen printed front contacts with a peak wafer temperature of approximately $850^{\circ} \mathrm{C}$ for about 3 seconds was done with $S_{\text {eff increasing to }}$ $<70 \mathrm{~cm} / \mathrm{s}$.

For the triple layer system $\left(\mathrm{SiO}_{x}, \mathrm{SiN}_{x}\right.$, and $\mathrm{SiO}_{x}$, in short: PECVD-ONO), the same thermal processing as for the two layer sample structure has been applied. This led to the following surface recombination velocities: as-deposited: below $240 \mathrm{~cm} / \mathrm{s}$, after annealing in forming gas at $425^{\circ} \mathrm{C}$ for 15 minutes: below $30 \mathrm{~cm} / \mathrm{s}$, after thermal processing comparable to firing of screen printed front contacts with a peak wafer temperature of approximately $850^{\circ} \mathrm{C}$ for about 3 seconds: below $60 \mathrm{~cm} / \mathrm{s}$.

The $S_{\text {eff }}$ results are summarised in Figure 6.

Both stack systems are suitable for the surface passivation of p-type Si wafers before and after a thermal treatment

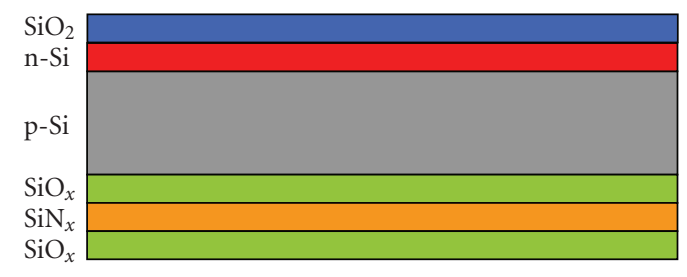

FIGURE 7: Sample structure of the solar cell precursors.

like the contact firing. After deposition and after annealing, a stronger passivation effect was found for the triple stack structure $\mathrm{SiO}_{x}+\mathrm{SiN}_{x}+\mathrm{SiO}_{x}$ (PECVD-ONO, Patent pending). This effect will be investigated further in the future. However, one beneficial effect is the increased overall layer thickness providing a higher probability for hydrogen to diffuse to the silicon/silicon oxide interface and lowering the amount of recombinatively active interface traps.

\subsection{Solar Cell Precursors}

An investigation of the suitability of the newly developed PECVD-ONO stack system for passivation of solar cell rear sides is presented here. A short summary has been shown in [27].

Float zone wafers with the following characteristics were used: p-type, boron doped, $0.5 \Omega \mathrm{cm}, 250 \mu \mathrm{m}$ thick, and shiny etched surface with a crystal orientation of (100). The wafers were oxidised, front side windows were opened by photolithography. Then, an emitter was diffused into the front $(120 \Omega /$ sq.) followed by a wet chemical etch of the phosphorous silicate glass (PSG). In a second oxidation step, an antireflecting $\mathrm{SiO}_{2}$ layer was grown on the front (and the oxide on the back was thickened). After removing the oxide on the rear and cleaning the surface in a wet chemical bath sequence of (i) $\mathrm{HNO}_{3}$ and (ii) $\mathrm{HF}$, the novel passivation stack PECVD-ONO has been deposited on the rear and the lifetime was measured. Subsequently, the samples were annealed at $425^{\circ} \mathrm{C}$ for 15 minutes in forming gas and/or a thermal treatment comparable to the firing of screen printed front contacts was performed. After each thermal process, the lifetime was measured using the QSSPC technique. The sample structure can be found in Figure 7 and the process sequence in Figure 8. 


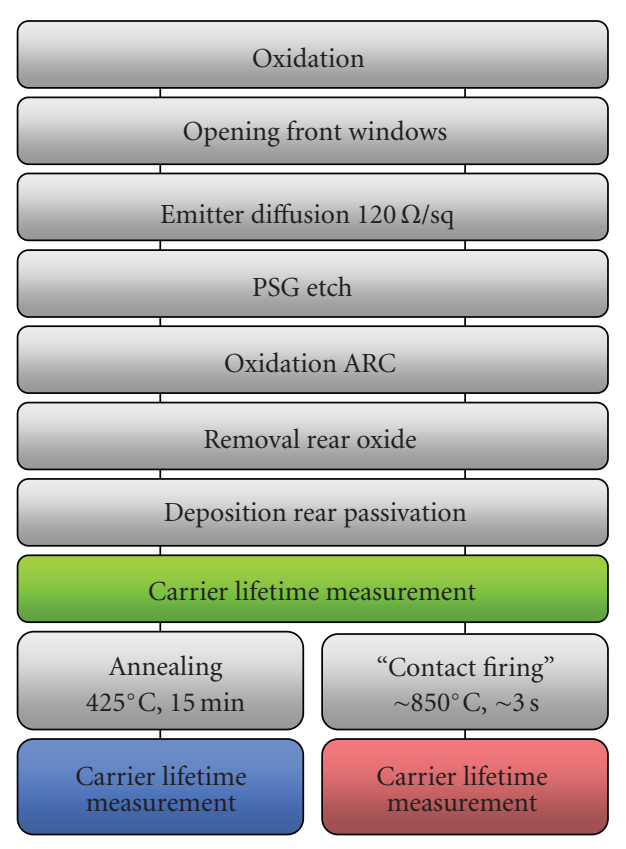

Figure 8: Process sequence of the solar cell precursor experiment. The colours correspond to the colours in Figure 9.

It can be summarised that the sample structure equals a finished solar cell except the metal contacts on front and rear.

Cuevas and Sinton have shown that implied $V_{\text {oc }}$ values can be extracted from the measured effective minority carrier lifetimes $[32,33]$ using an approximation equation for $V_{\text {oc }}$ :

$$
V_{\mathrm{oc}}=\frac{k T}{q} \ln \left(\frac{n p}{n_{i}^{2}}\right),
$$

with Boltzmann's constant $k$, temperature $T$, elementary charge $q$, free-electron density $n$, free-hole density $p$, and intrinsic free-electron density $n_{i}$.

For p-type wafers and long diffusion lengths, (2) can be written as $[32,33]$

$$
V_{\mathrm{oc}}=\frac{k T}{q} \ln \left(\frac{\Delta n\left(\Delta p+N_{A}\right)}{n_{i}^{2}}\right),
$$

with $N_{A}$ being the density of acceptors.

$n_{i}$ can be calculated from

$$
n_{i}=N_{C} N_{V} e^{-E_{g} / k T}
$$

with silicon's density of states in the conduction band $N_{C}$ and in the valence band $N_{V}$ and the silicon band gap energy $E_{g}$. Hence, one can calculate Implied $V_{\text {oc }}$ values from QSSPC measurements. The implied $V_{\mathrm{oc}}$ was extracted at 1 sun. Initially, $V_{\mathrm{oc}}$ values of approximately $631 \mathrm{mV}$ have been observed. After annealing or firing, the implied $V_{\text {oc }}$ values increased strongly to values above $680 \mathrm{mV}$. Here, the results after firing were very similar regardless of whether an annealing was done prior to the firing step or not. The effect is suspected to be due to an enhancement of the front and rear surface passivation. See Figure 9.

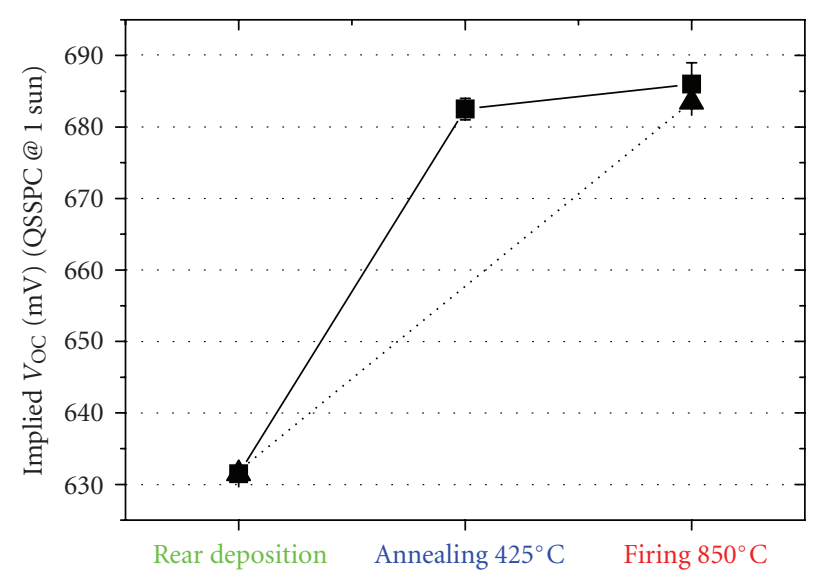

FIGURE 9: Solar cell precursors. Implied $V_{\text {oc }}$ values extracted from QSSPC measurements at 1 sun show a strong increase after thermal treatment. Colours correspond to Figure 8.

\section{Hydrogen Depth Profiling}

For the passivation effect, the diffusion of hydrogen from the strongly hydrogenated silicon nitride layer to the $\mathrm{SiO}_{x} /$ bulk Si interface might be responsible. Typically, a high density of recombinatively active states at this interface can be found. These states, mostly Si dangling bonds, can be saturated by hydrogen and implicitly made recombinatively inactive. Therefore, the hydrogen concentration and the change in hydrogen concentration in different layers within the passivation stack system is of great interest.

Nuclear reaction analysis (NRA) measurements have been performed at Forschungszentrum Dresden-Rossendorf, Germany [34]. NRA is based on a reaction between a nitrogen isotope ${ }^{15} \mathrm{~N}$ which is accelerated to several $\mathrm{MeV}$ and a hydrogen atom ${ }^{1} \mathrm{H}$ in the sample. The reaction only takes place when the nitrogen atom has a specific kinetic resonance energy $(6.385 \mathrm{MeV})$. At lower energy, no nuclear reaction will happen. At higher energy, the nitrogen atom looses speed (energy) while passing through the first atomic layers of the film. When the nitrogen is decelerated to the resonance energy, the reaction will happen if there is a hydrogen atom to react with (Figure 10). The reaction of hydrogen and nitrogen will finally lead to a ${ }^{12} \mathrm{C}$ atom and an alpha particle and a gamma quantum that are radiated. The reaction equations are as follows:

$$
\begin{gathered}
{ }^{15} \mathrm{~N}+{ }^{1} \mathrm{H} \longrightarrow{ }^{16} \mathrm{O}^{*} \longrightarrow{ }^{12} \mathrm{C}^{*}+\alpha \\
{ }^{12} \mathrm{C}^{*} \longrightarrow{ }^{12} \mathrm{C}+\gamma .
\end{gathered}
$$

Counting the measured gamma quanta for a certain nitrogen kinetic leads to the hydrogen concentration and the depth profile [34].

Silicon wafer samples comparable to the symmetrical lifetime samples were used for the NRA measurement [27]. The process state of the samples under investigation was as-deposited, after annealing $\left(425^{\circ} \mathrm{C}, 15 \mathrm{~min}\right)$ and after firing $\left(850^{\circ} \mathrm{C}, \sim 3 \mathrm{~s}\right)$. The hydrogen depth profiling of the as-deposited sample showed a hydrogen concentration 


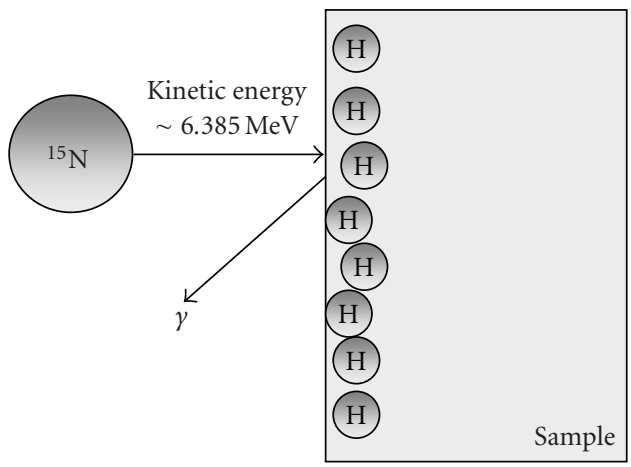

(a)

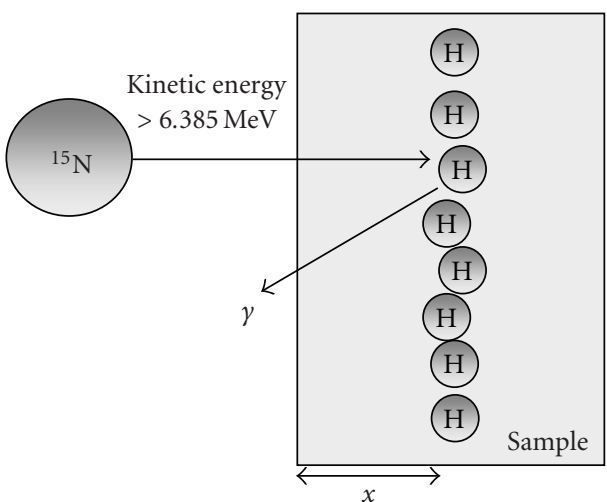

(b)

FIGURE 10: Measurement principle of the nuclear reaction analysis (NRA) technique (after [35]). The intensity of gamma radiation for a known kinetic energy of ${ }^{15} \mathrm{~N}$ above the threshold energy of $6.385 \mathrm{MeV}$ is correlated with the depth of hydrogen.

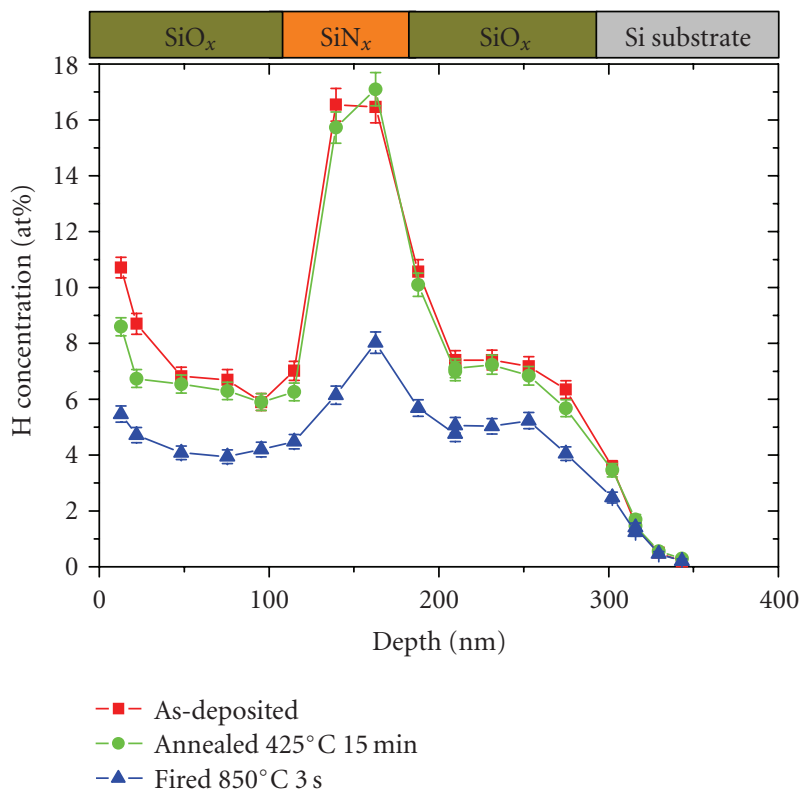

FIGURE 11: Results of the hydrogen depth profiling using the NRA method. Samples with PECVD-ONO after a variation of thermal treatment are shown: as-deposited, after annealing $\left(425^{\circ} \mathrm{C}, 15 \mathrm{~min}\right)$, after firing $\left(850^{\circ} \mathrm{C}, \sim 3 \mathrm{~s}\right.$, sample not annealed prior to firing).

of approximately 8 at $\%$ in the PECVD $\mathrm{SiO}_{x}$ films and approximately 16 at $\%$ in the $\mathrm{SiN}_{x}$ film. Almost no hydrogen could be found within the crystalline silicon bulk. After annealing the hydrogen depth profile did not change much. Hence, no strong hydrogen diffusion could be observed. The sample that was subjected to the "contact firing" showed a significantly modified hydrogen profile. As expected at this temperature range, hydrogen was very mobile. The overall hydrogen concentration was lowered, within the $\mathrm{SiO}_{x}$ layers approximately 5 at $\%$ hydrogen could be found and a peak concentration of approximately 8 at $\%$ was observed within the $\mathrm{SiN}_{x}$ layer. This shows that a strong out-diffusion (i) from the hydrogenated layers to the ambient and (ii) from the

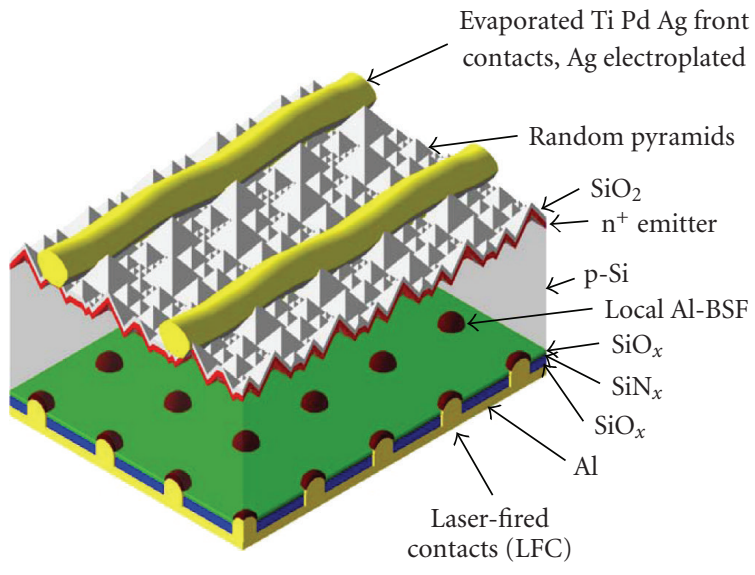

FIGURE 12: Structure of the fabricated solar cells with the newly developed passivation stack system PECVD-ONO on the rear and LFC contacts.

nitride film to the surrounding oxide layers took place. No significant effect can be observed at the $\mathrm{SiO}_{x} / \mathrm{c}$-Si interface (see Figure 11).

\section{Solar Cell Fabrication}

Finally, solar cells with the newly developed passivation stack system PECVD-ONO were fabricated to show the quality of the passivation on a final cell.

Starting the cell fabrication using float-zone Si substrates with the same characteristics as in the above experiments, the final cells exhibit evaporated TiPdAg front contacts, a thermally oxidised antireflection coating that also serves as front passivation layer, a $120 \Omega$ /sq n-type emitter, fabricated by diffusion using a $\mathrm{POCl}_{3}$ ambient, a $1 \Omega \mathrm{cm}$ p-type bulk, the newly developed PECVD-ONO stack passivation system, and an evaporated $\mathrm{Al}$ layer at the back and laser-fired contacts that led to a local Al-BSF underneath (above if looking at Figure 12) the point contacts. The rear surface was 


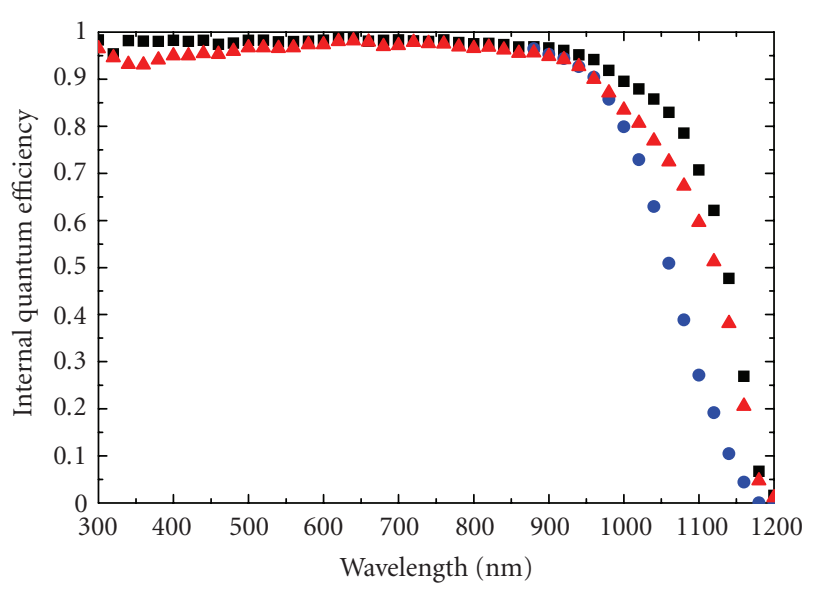

- Thermal $\mathrm{SiO}_{2}$

- Al-BSF

$\triangle$ PECVD-ONO

FIGURE 13: Internal quantum efficiency for cells of this batch with thermal $\mathrm{SiO}_{2}$ and PECVD-ONO rear passivation and high-quality Al-BSF rear passivation of another batch.

TABLE 1: Best solar cells of this investigation.

\begin{tabular}{lccccc}
\hline Rear passivation & Area & $V_{\mathrm{oc}}$ & $J_{\mathrm{sc}}$ & FF & $\eta$ \\
\hline PECVD-ONO & $4.0 \mathrm{~cm}^{2}$ & $664 \mathrm{mV}$ & $38.2 \mathrm{~mA} / \mathrm{cm}^{2}$ & $78.7 \%$ & $20.0 \%$ \\
Thermal SiO & $4.0 \mathrm{~cm}^{2}$ & $676 \mathrm{mV}$ & $38.3 \mathrm{~mA} / \mathrm{cm}^{2}$ & $80.4 \%$ & $20.8 \%$ \\
\hline
\end{tabular}

cleaned in a wet chemical bath sequence of (i) $\mathrm{HNO}_{3}$ and (ii) HF.

The cell scheme can be found in Figure 12.

The final cell was annealed at $425^{\circ} \mathrm{C}$ in forming gas for 15 minutes. A thermal process comparable to the firing of screen printed front contacts (as used in the lifetime experiments described above) was not applied. This process would harm the solar cell structure used in this batch.

The best solar cell with the novel PECVD-ONO stack system as rear passivation led to a cell efficiency of $20.0 \%$ (see Table 1).

For comparison also thermally grown silicon dioxide was used for rear passivation within the same solar cell batch that is known for its excellent rear passivation quality. $20.8 \%$ peak efficiency could be obtained for these reference cells.

Internal quantum efficiency (IQE) measurements (Figure 13) allow for a comparison of the quality of the novel rear passivation PECVD-ONO stack with thermally grown $\mathrm{SiO}_{2}$ as well as with full area high-quality Al-BSF (the Al-BSF cells originated from a different but similar solar cell batch). It could be proven that PECVD-ONO is superior to Al-BSF rear sides but shows lower quality than thermally grown $\mathrm{SiO}_{2}$.

To quantify the rear passivation quality in the finished solar cell, a numerical fit to the experimental external quantum efficiency (EQE), IQE, and reflection properties was prepared using PC1D [1]. The graphical results can be found in Figure 14. The total front and rear surface recombination velocities can be derived from the PC1D fit as $3200 \mathrm{~cm} / \mathrm{s} \pm 500 \mathrm{~cm} / \mathrm{s}$ (front) and $550 \mathrm{~cm} / \mathrm{s} \pm 50 \mathrm{~cm} / \mathrm{s}$

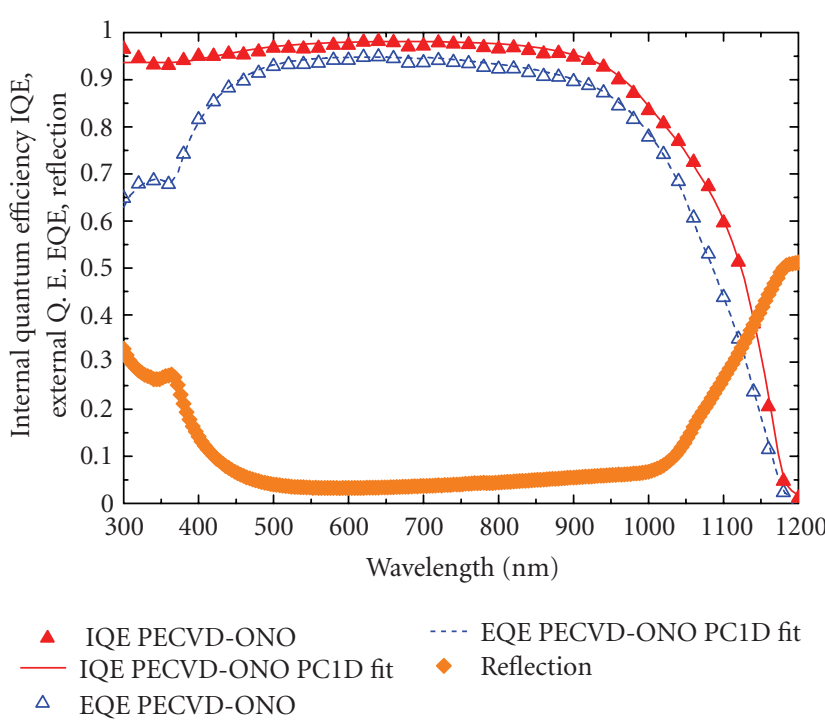

FIGURE 14: External quantum efficiency, IQE and reflection values for the solar cell using PECVD-ONO rear passivation. Experimental data (symbols) and calculated values (lines) are displayed. The calculation was done using PC1D [1].

(rear), respectively. This includes the recombination at the passivated area as well as the contact area. Fischer presented an equation describing the SRV of locally contacted solar cell rear sides [36]

$$
\begin{aligned}
S_{\text {eff }}= & \frac{D}{W}\left(\frac{L_{p}}{2 W \sqrt{\pi f}} \arctan \left(\frac{2 W}{L_{p}} \sqrt{\frac{\pi}{f}}\right)-e^{-W / L_{p}}+\frac{D}{f W S_{\text {met }}}\right)^{-1} \\
& +\frac{S_{\text {pass }}}{1-f},
\end{aligned}
$$

with the minority carrier diffusion constant $D$, the wafer thickness $W$, the contact pitch $L_{p}$, the metallisation fraction $f$, the SRV of the metallised surface $S_{\text {met }}$, and the SRV of the passivated surface $S_{\text {pass }}$ of the rear side. For the cells presented here, the following values are valid: $D_{n}=27.1 \mathrm{~cm}^{2} / \mathrm{s}, W=$ $240 \mu \mathrm{m}, L_{p}=1 \mathrm{~mm}$, and $f=1 \%$. Kray and Glunz have experimentally investigated and modelled the recombination velocity at the laser-fired contacts leading to the expression [37]

$$
S_{\text {met }}\left(N_{A}\right)=S_{0}+\alpha e^{\beta\left(N_{A}+N_{0}\right)},
$$

with $S_{0}=-900 \mathrm{~cm} / \mathrm{s}, \alpha=22.1 \mathrm{~cm} / \mathrm{s}, \beta=1.29 \times 10^{-16} \mathrm{~cm}^{3}$, and $N_{0}=3.40 \times 10^{16} \mathrm{~cm}^{-3}$ and $N_{A}$ being the density of acceptors in the substrate (in our case $1.5 \times 10^{16} \mathrm{~cm}^{-3}$ ).

Hence, by using the above equations and the $S_{\text {eff }}$ value extracted from PC1D, $S_{\text {pass }}$ can be calculated to $500 \mathrm{~cm} / \mathrm{s} \pm$ $50 \mathrm{~cm} / \mathrm{s}$.

\section{Conclusion}

A novel surface passivation stack comprising of three PECVD layers was presented. The stack consists of $\mathrm{a}-\mathrm{SiO}_{x}: \mathrm{H}$, a$\mathrm{SiN}_{x}: \mathrm{H}$, and $\mathrm{a}-\mathrm{SiO}_{x}: \mathrm{H}$. Lifetime measurements with the 
novel stack system on both surfaces of p-type silicon wafers showed surface recombination velocities of $<240 \mathrm{~cm} / \mathrm{s}$, after annealing at $425^{\circ} \mathrm{C}:<30 \mathrm{~cm} / \mathrm{s}$, after firing: $<60 \mathrm{~cm} / \mathrm{s}$. Solar cell precursors without metallisation but with $\mathrm{PECVD}-\mathrm{ONO}$ rear passivation exhibited implied $V_{\text {oc }}$ values extracted from the QSSPC measurements of $>680 \mathrm{mV}$. Hydrogen depth profiling using the NRA method was conducted resulting in hydrogen concentrations of approximately 8 at $\%$ in the PECVD $\mathrm{SiO}_{x}$ films and approximately 16 at $\%$ in the $\mathrm{SiN}_{x}$ film in the as-deposited and annealed state. After firing, the hydrogen concentrations were strongly lowered to 5 at $\%$ in the PECVD $\mathrm{SiO}_{x}$ films and approximately 8 at $\%$ in the $\mathrm{SiN}_{x}$ film.

Solar cells with the novel passivation stack were processed and showed efficiencies of up to $20.0 \%$. IQE characterisation and modelling using PC1D led to a total SRV at the rear surface of $550 \mathrm{~cm} / \mathrm{s} \pm 50 \mathrm{~cm} / \mathrm{s}$. Additionally, the model for the recombination at locally contacted rear sides by Fischer and Kray led to an SRV of $500 \mathrm{~cm} / \mathrm{s} \pm 50 \mathrm{~cm} / \mathrm{s}$ at the passivated area.

A patent on the novel PECVD-ONO passivation stack system is pending.

\section{Acknowledgments}

The authors would like to thank A. Leimenstoll, A. Herbolzheimer, and S. Seitz for clean room processing. The laser processing was supported by J.F. Nekarda, B. Fleischhauer, C. Harmel, and A. Grohe. Additionally, the authors thank K. Krüger for Ag plating, T. Roth for lifetime measurements, and E. Schäffer and K. Kordelos for I-V measurements. This work was partly supported by the EU funded project "Crystal Clear” under the project number SES6-CT2003-502583.

\section{References}

[1] D. A. Clugston and P. A. Basore, "PC1D version 5: 32-bit solar cell modeling on personal computers," in Proceedings of the 26th IEEE Photovoltaic Specialists Conference, pp. 207-210, Anaheim, Calif, USA, September-October 1997.

[2] G. Agostinelli, P. Choulat, H. F. W. Dekkers, S. De Wolf, and G. Beaucarne, "Screen printed large area crystalline silicon solar cells on thin substrates," in Proceedings of the 20th European Photovoltaic Solar Energy Conference and Exhibition, pp. 647650, Barcelona, Spain, June 2005.

[3] D. Kray, Hocheffiziente solarzellenstrukturen für kristallines silicium-material industrieller qualität, Ph.D. dissertation, Universität Konstanz, Konstanz, Germany, 2004.

[4] A. W. Blakers, A. Wang, A. M. Milne, J. Zhao, and M. A. Green, "22.8\% efficient silicon solar cell," Applied Physics Letters, vol. 55, no. 13, pp. 1363-1365, 1989.

[5] E. Schneiderlöchner, R. Preu, R. Lüdemann, and S. W. Glunz, "Laser-fired rear contacts for crystalline silicon solar cells," Progress in Photovoltaics: Research and Applications, vol. 10, no. 1, pp. 29-34, 2002.

[6] S. W. Glunz, E. Schneiderlöchner, D. Kray, et al., "Laser-fired contact solar cells on p- and n-type substrates," in Proceedings of the 19th European Photovoltaic Solar Energy Conference and Exhibition, pp. 408-411, Paris, France, June 2004.
[7] F. Granek, M. Hermle, B. Fleischhauer, et al., "Optimisation of laser-fired aluminium emitters for high efficiency n-type si solar cells," in Proceedings of the 21st European Photovoltaic Solar Energy Conference and Exhibition, pp. 777-780, Dresden, Germany, September 2006.

[8] S. W. Glunz, A. Grohe, M. Hermle, et al., "Comparison of different dielectric passivation layers for application in industrially feasible high-efficiency crystalline silicon solar cells," in Proceedings of the 20th European Photovoltaic Solar Energy Conference and Exhibition, pp. 572-577, Barcelona, Spain, June 2005.

[9] J. Schmidt and A. G. Aberle, "Easy-to-use surface passivation technique for bulk carrier lifetime measurements on silicon wafers," Progress in Photovoltaics: Research and Applications, vol. 6, no. 4, pp. 259-263, 1998.

[10] H. Mäckel and R. Lüdemann, "Detailed study of the composition of hydrogenated $\mathrm{SiN}_{\mathrm{x}}$ layers for high-quality silicon surface passivation," Journal of Applied Physics, vol. 92, no. 5, pp. 2602-2609, 2002.

[11] M. Hofmann, E. Schneiderlöchner, W. Wolke, and R. Preu, "Silicon nitride-silicon oxide stacks for solar cell rear side passivation," in Proceedings of the 19th European Photovoltaic Solar Energy Conference and Exhibition, pp. 1037-1040, Paris, France, June 2004.

[12] I. G. Romijn, W. J. Soppe, H. C. Rieffe, A. R. Burgers, and A. W. Weeber, "Passivation mc-Si solar cells using $\mathrm{SiN}_{\mathrm{x}}: \mathrm{H}$ : from magic to physics," in Proceedings of the 20th European Photovoltaic Solar Energy Conference and Exhibition, pp. 13521355, Barcelona, Spain, June 2005.

[13] S. De Wolf, Rear passivation for thin base low-cost silicon solar cells, Ph.D. dissertation, Katholische Universität Leuven, Leuven, Belgium, 2005.

[14] F. Chen, I. Romijn, A. Weeber, J. Tan, B. Hallam, and J. Cotter, "Relationship between PECVD silicon nitride film composition and surface and edge passivation," in Proceedings of the 22nd European Photovoltaic Solar Energy Conference and Exhibition, pp. 1053-1060, Milan, Italy, September 2007.

[15] A. G. Aberle, Crystalline Silicon Solar Cells: Advanced Surface Passivation and Analysis of Crystalline Silicon Solar Cells, The University of New South Wales, Sydney, Australia, 1999.

[16] S. Dauwe, L. Mittelstädt, A. Metz, and R. Hezel, "Experimental evidence of parasitic shunting in silicon nitride rear surface passivated solar cells," Progress in Photovoltaics: Research and Applications, vol. 10, no. 4, pp. 271-278, 2002.

[17] S. Dauwe, Low-temperature surface passivation of crystalline silicon and its application to the rear side of solar cells, Ph.D. dissertation, Universität Hannover, Hannover, Germany, 2004.

[18] M. Schaper, J. Schmidt, H. Plagwitz, and R. Brendel, " $20.1 \%$ efficient crystalline silicon solar cell with amorphous silicon rear-surface passivation," Progress in Photovoltaics: Research and Applications, vol. 13, no. 5, pp. 381-386, 2005.

[19] P. J. Rostan, U. Rau, V. X. Nguyen, T. Kirchartz, M. B. Schubert, and J. H. Werner, "Low-temperature a-Si:H/ZnO/Al back contacts for high-efficiency silicon solar cells," Solar Energy Materials and Solar Cells, vol. 90, no. 9, pp. 1345-1352, 2006.

[20] S. De Wolf and G. Beaucarne, "Surface passivation properties of boron-doped plasma-enhanced chemical vapor deposited hydrogenated amorphous silicon films on p-type crystalline Si substrates," Applied Physics Letters, vol. 88, no. 2, Article ID 022104, 3 pages, 2006.

[21] H. Plagwitz, B. Terheiden, and R. Brendel, "Formation of defects at the amorphous silicon-crystalline silicon interface during annealing," in Proceedings of the 22nd European 
Photovoltaic Solar Energy Conference and Exhibition, pp. 936939, Milan, Italy, September 2007.

[22] W. Brendle, V. X. Nguyen, A. Grohe, et al., "20.5\% Efficient silicon solar cell with a low temperature rear side process using laser-fired contacts," Progress in Photovoltaics: Research and Applications, vol. 14, no. 7, pp. 653-662, 2006.

[23] M. Hofmann, S. W. Glunz, R. Preu, and G. Willeke, "21\%efficient silicon solar cells using amorphous silicon rear side passivation," in Proceedings of the 21st European Photovoltaic Solar Energy Conference and Exhibition, pp. 609-613, Dresden, Germany, September 2006.

[24] M. Hofmann, C. Schmidt, N. Kohn, et al., "Detailed analysis of amorphous silicon passivation layers deposited in industrial in-line and laboratory-type pecvd reactors," in Proceedings of the 22nd European Photovoltaic Solar Energy Conference and Exhibition, pp. 1528-1531, Milan, Italy, September 2007.

[25] G. Agostinelli, P. Choulat, H. F. W. Dekkers, E. Vermariën, and G. Beaucarne, "Rear surface passivation for industrial solar cells on thin substrates," in Proceedings of the 4th IEEE World Conference on Photovoltaic Energy Conversion, vol. 1, pp. 10041007, Waikoloa, Hawaii, USA, May 2006.

[26] B. Hoex, F. J. J. Peeters, M. Creatore, M. A. Blauw, W. M. M. Kessels, and M. C. M. van de Sanden, "High-rate plasmadeposited $\mathrm{SiO}_{2}$ films for surface passivation of crystalline silicon," Journal of Vacuum Science \& Technology A, vol. 24, no. 5, pp. 1823-1830, 2006.

[27] M. Hofmann, S. Kambor, C. Schmidt, et al., "Firing stable surface passivation using all-PECVD stacks of $\mathrm{SiO}_{\mathrm{x}}: \mathrm{H}$ and $\mathrm{SiN}_{\mathrm{x}}: \mathrm{H}$," in Proceedings of the 22nd European Photovoltaic Solar Energy Conference and Exhibition, pp. 1030-1033, Milan, Italy, September 2007.

[28] W. Kern and D. Puotinen, "Cleaning solutions based on hydrogen peroxide for use in silicon semiconductor technology," RCA Review, vol. 31, pp. 187-206, 1970.

[29] R. A. Sinton, A. Cuevas, and M. Stuckings, "Quasi-steadystate photoconductance, a new method for solar cell material and device characterization," in Proceedings of the 25th IEEE Photovoltaic Specialists Conference, pp. 457-460, Washington, DC, USA, May 1996.

[30] S. W. Glunz, D. Biro, S. Rein, and W. Warta, "Field-effect passivation of the $\mathrm{SiO}_{2}$-Si interface," Journal of Applied Physics, vol. 86, no. 1, pp. 683-691, 1999.

[31] A. B. Sproul, "Dimensionless solution of the equation describing the effect of surface recombination on carrier decay in semiconductors," Journal of Applied Physics, vol. 76, no. 5, pp. 2851-2854, 1994.

[32] A. Cuevas and R. A. Sinton, "Prediction of the open-circuit voltage of solar cells from the steady-state photoconductance," Progress in Photovoltaics: Research and Applications, vol. 5, no. 2, pp. 79-90, 1997.

[33] R. A. Sinton, "User Manual: WCT-100 Photoconductance Tool," Sinton Consulting. p. 60, 2003.

[34] W. Rudolph, C. Bauer, K. Brankoff, et al., "Plastic foils as primary hydrogen standards for nuclear reaction analysis," Nuclear Instruments and Methods in Physics Research B, vol. 15, no. 1-6, pp. 508-511, 1986.

[35] M. Schwickert, Neuaufbau eines Pelletron-Beschleunigers und Untersuchungen zum Laserhydrieren von Silizium, Ph.D. dissertation, Georg-August-Universität, Göttingen, Germany, 2002.

[36] B. Fischer, Loss analysis of crystalline silicon solar cells using photoconductance and quantum efficiency measurements, Ph.D. dissertation, Universität Konstanz, Konstanz, Germany, 2003.
[37] D. Kray and S. W. Glunz, "Investigation of laser-fired rear-side recombination properties using an analytical model," Progress in Photovoltaics: Research and Applications, vol. 14, no. 3, pp. 195-201, 2006. 

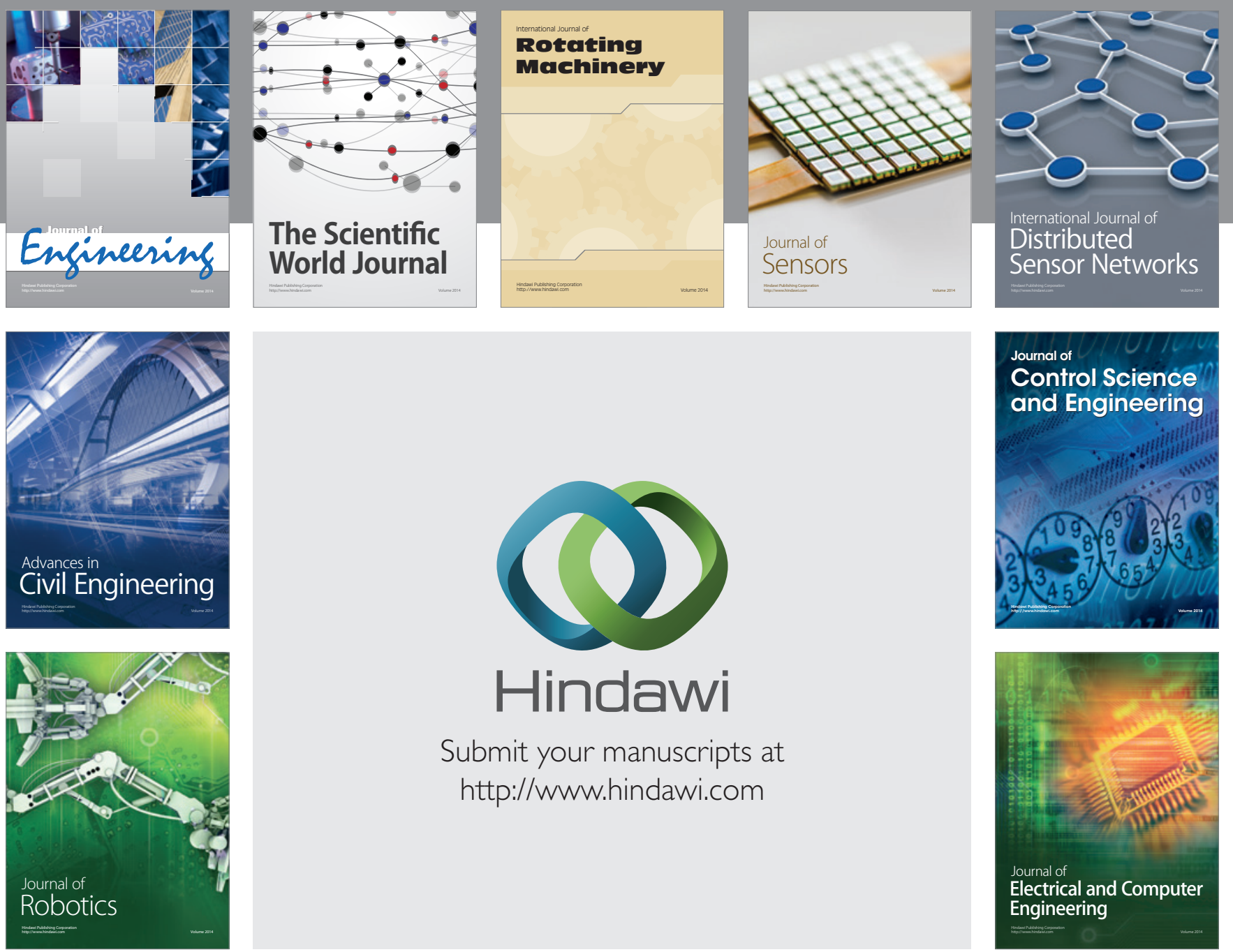

Submit your manuscripts at

http://www.hindawi.com
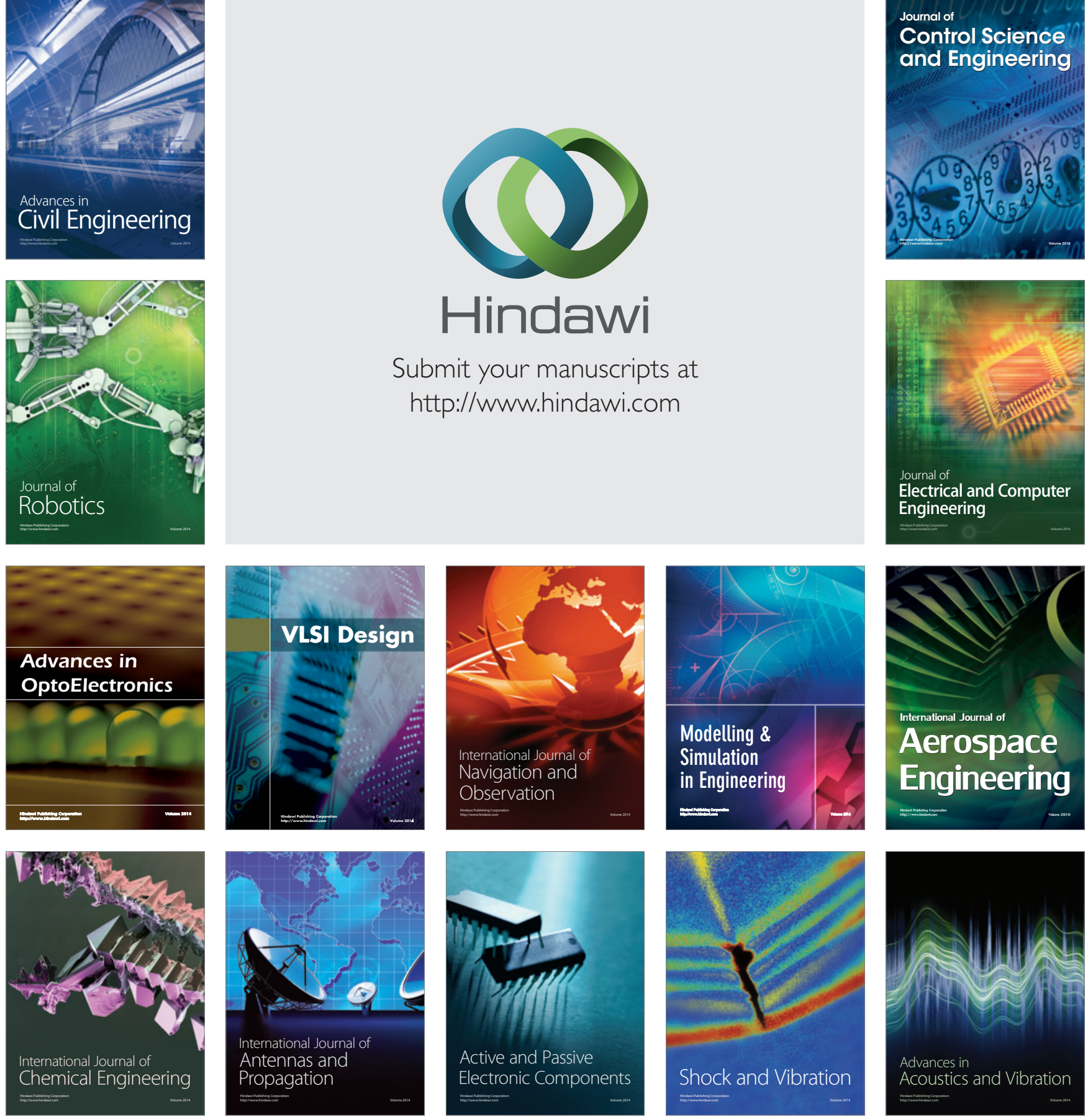